\title{
FAKTOR-FAKTOR YANG BERHUBUNGAN DENGAN TINGKAT KECEMASAN PASIEN TUBERKULOSIS PARU PADA SATU RUMAH SAKIT DI KABUPATEN GARUT
}

\author{
Hendrawati*, Iceu Amira Da* \\ *PSDKU Universitas Padjadjaran Kampus Garut
}

\begin{abstract}
Tuberkulosis paru adalah masalah kesehatan masyarakat yang penting di dunia. Indonesia adalah urutan nomor 3 di asia dalam jumlah pasien dengan tuberculosis paru (WHO, 2009). Dari beberapa penyakit menular yang ditangani di RSUP Dr.Slamet Garut selama tahun 2013 kejadian pasien tuberkulosis paru masih tinggi sebanyak 2.100 pasien. Salah satu komplikasi tuberkulosis paru adalah gangguan psikologis seperti kecemasan. Tujuan penelitian ini adalah untuk mengetahui faktor-faktor yang berhubungan dengan tingkat kecemasan pada pasien tuberkulosis paru di Rumah Sakit Umum Pusat Dr. Slamet Garut. Penelitian termasuk penelitian deskriptif korelatif dengan menggunakan cross-sectional dengan populasi 62 orang. Teknik pengambilan sampel purposive sampling untuk memperoleh sampel sebanyak 54 orang. Teknik pengumpulan data dengan kuesioner. Analisis ini menggunakan uji Chi - Square univariat dan bivariat. Hasilnya menunjukkan; Ada hubungan antara tingkat pengetahuan tentang tingkat kecemasan ( $p$ value $=0,008)$, Ada hubungan antara usia dan tingkat kecemasan $(p$-value $=0,002)$, Ada hubungan antara jenis kelamin dengan tingkat kecemasan $(p$-value $=0,008)$, Ada hubungan antara tingkat pendidikan dan tingkat kecemasan ( $p$-value $=0,001)$, Ada hubungan antara status ekonomi dengan tingkat kecemasan $(p$ value $=0,003)$. Berdasarkan hasil penelitian, yang perlu ditingkatkan pelayanan keperawatan; konseling tentang tuberkulosis, memberikan dukungan sosial kepada pasien yang lebih tua, memberikan motivasi kepada pasien wanita, dan kerjasama lintas sektoral.
\end{abstract}

Kata kunci: Kecemasan, tuberkulosis, pengetahuan, usia, jenis kelamin, tingkat pendidikan, status ekonomi

\section{LATAR BELAKANG}

Tuberkulosis (TB) Paru merupakan masalah kesehatan masyarakat yang penting didunia ini.Indonesia merupakan urutan nomor 3 di asia dalam jumlah penderita TB Paru setelah India dan China (WHO, 2009). Pada tahun 2009 Indonesia menduduki peringkat ke lima di dunia setelah India, Cina, South Afrika, dan Nigeria dengan jumlah prevalensi 285/100.000 penduduk, dan angka kematian telah turun menjadi 27/100.000 penduduk (Kemenkes, 2011).

Prevalensi TB Paru di Indonesia masih cukup tinggi diantara Negara-negara ASEAN lain mencapai 285 orang per 100.000 penduduk (Depkes, 2012). Secara kasar di perkirakan pada setiap 100.000 penduduk Indonesia terdapat 130 penderita TB Paru dengan BTA (Basil Tahan Asam) positif (Depkes, 2012). Penderita TB Paru di Jawa Barat tercatat sekitar 61.429 jiwa dan yang meninggal sebanyak 150 orang (Dinkes Jabar, 2012). Berdasarkan data Dinas Kesehatan Kabupaten Garut tahun 2012, jumlah penderita TB Paru BTA positif yang berhasil ditemukan dan di obati berjumlah 1.659 orang, sisanya sebanyak 890 orang belum ditemukan.

Tuberkulosis adalah penyakit menular langsung yang disebabkan oleh kuman TB (Mycobacterium tuberculosis), sebagian besar kuman TB menyerang paru, tetapi dapat juga mengenai organ tubuh lainnya (Manaf, dkk, 2006). Tuberkulosis merupakan penyakit infeksi menular yang berbahaya yang disebabkan oleh kuman TB dengan gejala yang bervariasi. Setiap penderita tuberkulosis dapat menularkan penyakitnya pada orang lain yang berada disekelilingnya dan atau yang berhubungan erat dengan penderita (Jaorana, dkk, 2009). Umumnya menyerang paru, tetapi bisa juga menyerang bagian tubuh lainnya seperti 
kelenjar getah bening, selaput otak, kulit, tulang dan persendian, usus, ginjal dan organ tubuh lainnya (PPTI, 2010).

Pasien TB dengan keadaan umum masih baik tanpa komplikasi lanjut di indikasikan untuk rawat jalan sementara pasien TB yang sudah mengalami komplikasi lanjut dengan keadaan umum tidak baik di indikasikan untuk rawat inap (Jaorana, dkk, 2009). Menurut Nanda (2006) masalah yang dapat terjadi pada pasien yang mengalami TB Paru diantaranya : Bersihan jalan nafas tidak efektif akibat adanya akumulasi sekret, Infeksi resiko tinggi penularan, Rasa nyaman nyeri karena kontraksi otot pernafasan yang secara terus-menerus tanpa disertai relaksasi, Sesak napas yang terjadi karena adanya jalan napas yang tidak efektif sehubungan dengan eksudasi cairan rongga pleura yang menyebabkan rangsangan pada impuls saraf pusat lapar yaitu hypothalamus sehingga menimbulkan anorexia. Gangguan Istirahat tidur karena adanya sesak napas sebagai kegiatan pada system pengaktivasi retukulasis sehingga tidur terganggu, Penurunan suplai oksigen akan menghambat metabolisme sebagai sumber energi terhambat maka akan menyebabkan keluhan dan kelemahan, Rasa cemas akibat kurangnya pengetahuan tentang penyakitnya.

Pengobatan TB Paru dilakukan secara bertahap dan teratur, tahapan pengobatan TB Paru diantaranya tahap intensif dan tahap lanjutan. Untuk itu para penderita harus mengenal, memahami, bagaimana cara pencegahan, tanda gejala dan penatalaksanaan dari TB Paru. TB Paru dapat sembuh bila dilakukan pengobatan secara teratur selama 6-8 bulan. Karena pengobatan memerlukan waktu yang lama maka penderita TB Paru sangat memungkinkan mengalami stress yang cukup berat (Rachmawati \& Turniani, 2006). Tuberkulosis pada penderita memiliki tanda dan gejala seperti perilaku tidak biasa dan perubahan status mental, demam, anoreksia, dan penurunan berat badan (Smeltzer dan Bare, 2008).
Penyakit TB paru bila tidak ditangani dengan benar akan menimbulkan komplikasi. Komplikasi dibagi atas komplikasi dini (pleuritis, efusi pleura, laryngitis, menjalar ke organ lain seperti usus) dan komplikasi lanjut (kerusakan parenkim berat, karsinoma paru). Komplikasi psikologis juga dapat di timbulkan dari penyakit tuberkulosis yakni bahwa setiap orang memiliki reaksi yang berbeda-beda ketika dihadapkan dengan suatu penyakit, reaksi perilaku dan emosi tersebut tergantung pada penyakit, sikap orang tersebut dalam menghadapi suatu penyakit, reaksi orang lain terhadap penyakit yang dideritanya, dan lain-lain. Penyakit dengan jangka waktu yang singkat dan tidak mengancam kehidupan hanya sedikit menimbulkan sedikit perubahan perilaku dalam fungsi orang tersebut dan keluarga, sedangkan penyakit berat seperti tuberkulosis paru yang dapat mengancam kehidupan dapat menimbulkan perubahan emosi dan perilaku yang lebih luas, seperti ansietas, syok, penolakan, marah, dan menarik diri (Perry \& Potter, 2005).

Salah satu perubahan emosi dari penyakit tuberkulosis adalah ansietas/kecemasan. Kecemasan (ansietas/ anxiety) adalah gangguan alam perasaan (affectiv) yang ditandai dengan perasaan ketakutan atau kekhawatiran yang mendalam dan berkelanjutan, tidak mengalami gangguan dalam menilai realitas (Reality Testing Ability), kepribadian masih tetap utuh, perilaku dapat terganggu tetapi masih dalam batas batas normal. Ada segi yang disadari dari kecemasan itu sendiri seperti rasa takut, tidak berdaya, terkejut, rasa berdosa atau terancam, selain itu juga segi - segi yang terjadi di luar kesadaran dan tidak dapat menghindari perasaan yang tidak menyenangkan (Jatman, 2001).

Tingkat kecemasan dipengaruhi oleh beberapa faktor yang terkait meliputi hal berikut: Potensi stressor ; Stresor psikososial adalah setiap keadaan atau peristiwa yang menyebabkan perubahan dalam kehidupan seseorang. Status pendidikan dan status ekonomi ; Status 
pendidikan dan status ekonomi yang rendah pada seseorang menyebabkan orang tersebut lebih mudah mengalami cemas dan stres dibanding dengan mereka yang status pendidikan dan status ekonomi yang tinggi. Tingkat pengetahuan ; Tingkat pengetahuan yang rendah pada seseorang akan menyebabkan orang tersebut mudah stress dan cemas.Semakin banyak pengetahuan yang dimiliki seseorang maka seseorang tersebut akan lebih siap menghadapi sesuatu dan dapat mengurangi kecemasan.

Ketidaktahuan terhadap suatu hal dianggap sebagai tekanan yang dapat mengakibatkan krisis dan dapat menimbulkan kecemasan. Stress dan kecemasan dapat terjadi pada individu dengan tingkat pengetahuan yang rendah, disebabkan karena kurangnya informasi yang diperoleh. Keadaan fisik ; Individu yang mengalami gangguan fisik seperti cidera, penyakit badan, operasi, cacat badan lebih mudah mengalami cemas dan stres.Tipe kepribadian ; Individu dengan tipe kepribadian tipe A lebih mudah mengalami gangguan akibat adanya cemas dan stres dari individu dengan kepribadian B. Sosial Budaya ; cara hidup individu di masyarakat yang sangat mempengaruhi pada timbulnya stres. Individu yang mempunyai cara hidup sangat teratur dan mempunyai falsafat hidup yang jelas maka pada umumnya lebih sukar mengalami stres. Demikian juga keyakinan agama akan mempengaruhi timbulnya stres. Lingkungan atau situasi ; Individu yang tinggal pada lingkungan yang dianggap asing akan lebih mudah mangalami cemas dan stress. Usia ; Ada yang berpendapat bahwa faktor usia tua lebih mudah mengalami cemas dan stres dari pada usia muda. Jenis kelamin ; Umumnya wanita lebih mudah mengalami cemas dan stres, tetapi usia harapan hidup wanita lebih tinggi dari pada pria (Isaacs, 2004).

Dari data yang diperoleh ketika melakukan pendataan awal terdapat 5 dari beberapa penyakit infeksi menular yang ditangani RSUD Dr.Slamet Garut selama tahun 2013 yaitu : TB Paru 2100 orang, konjungtivitis 1509 orang, dermatitis 751 orang, hepatitis 187 orang, HIV 3 orang. Dari data tersebut terlihat bahwa angka kejadian penyakit TB masih tinggi (Medical Record RSUD Dr.Slamet, 2013).

Setelah dilakukan studi pendahuluan dari 12 pasien ternyata 9 diantaranya kurang mengetahui sepenuhnya tentang TB Paru, 8 diantaranya berusia $>50$ tahun, 8 diantaranya berjenis kelamin perempuan, 9 diantaranya berpenghasilan sekitar Rp. 1.000.000-Rp. 2.000.000 per bulan, 5 diantaranya berpendidikan hanya lulus SMP, 3 tidak tamat SD, 2 lulusan SMA, 2 lulusan SD. Dari 12 pasien tersebut 7 diantaranya mengalami gelisah, khawatir dengan keadaan nya, dan emosi tidak stabil.

\section{METODE}

Penelitian ini termasuk penelitian deskriptif korelatif, karena peneliti ingin mengetahui hubungan antara tingkat pengetahuan, jenis kelamin, umur, tingkat pendidikan, dan status ekonomi dengan tingkat kecemasan pada pasien TB Paru. Penelitian ini menggunakan pendekatan Cross Sectional. Pada pendekatan Cross Sectional ini, penelitian menekankan waktu pengukuran/observasi data variabel independen dan dependen dinilai secara simultan pada suatu saat, jadi tidak ada tindak lanjut. Adapun varibel bebas dalam penelitian ini adalah Tingkat pengetahuan, usia, jenis kelamin, status pendidikian, dan status ekonomi, sedangkan variabel terikat dalam penelitian ini adalah tingkat kecemasan.

Populasi dalam penelitian ini adalah semua pasien TB Paru yang sedang dirawat di ruang penyakit Kecubung dan Zamrud RSUD Kabupaten Garut. Pemilihan sampel dilakukan dengan teknik pengambilan sampel Nonprobability sampling, dengan teknik Purposive sampling.Purposive sampling adalah suatu teknik penetapan sampel dengan cara memilih sampel diantara populasi sesuai dengan yang dikehendaki peneliti (tujuan/masalah dalam penelitian), sehingga sampel tersebut dapat mewakili 
karakteristik populasi yang telah dikenal sebelumnya (Nursalam, 2003). Jumlah sampel yaitu 54 orang.Dalam penelitian ini, instrumen penelitian yang digunakan adalah kuesioner yang disampaikan langsung kepada responden untuk mengetahui tingkat pengetahuan, umur, jenis kelamin, status pendidikan, dan status ekonomi.Sedangkan untuk mengukur tingkat kecemasan digunakan lembar kuesioner ZSAS meliputi tanda dan gejala cemas.

\section{HASIL}

\section{Analisis Univariat}

Tabel 1: Distribusi Frekuensi Responden Berdasarkan Pengetahuan

\begin{tabular}{|c|c|c|}
\hline Pengetahuan & $\mathrm{f}$ & $\%$ \\
\hline Baik & 4 & 7.4 \\
\hline Cukup & 17 & 31.5 \\
\hline Kurang & 33 & 61.5 \\
\hline Jumlah & 54 & 100 \\
\hline
\end{tabular}

Berdasarkan tabel di atas dapat dilihat bahwa tingkat pengetahuan pada 54 responden sebagian besar responden berpengetahuan kurang $(61.5 \%)$.

Tabel 2: Distribusi Frekuensi Responden Berdasarkan Usia

\begin{tabular}{lccc}
\hline & Usia & f & $\%$ \\
\hline Muda & & 21 & 38.9 \\
\hline Tua & & 33 & 61.1 \\
\hline & Jumlah & 54 & 100 \\
\hline
\end{tabular}

Berdasarkan tabel di atas dapat dilihat bahwa usia pada 54 responden sebagian besar responden berusia tua $(61.1 \%)$.

Tabel 3: Distribusi Frekuensi Responden Berdasarkan Jenis Kelamin

\begin{tabular}{ccc}
\hline \multicolumn{1}{c}{ Jenis Kelamin } & f & $\%$ \\
\hline Laki-laki & 23 & 42.6 \\
\hline Perempuan & 31 & 57.4 \\
\hline \multicolumn{1}{c}{ Jumlah } & 54 & 100 \\
\hline
\end{tabular}

Berdasarkan tabel di atas dapat dilihat bahwa jenis kelamin pada 54 responden sebagian besar responden berjenis kelamin perempuan $(57.4 \%)$.

Tabel 4: Distribusi Frekuensi Responden Berdasarkan Tingkat Pendidikan

\begin{tabular}{|c|c|c|}
\hline Tingkat Pendidikan & $\mathrm{f}$ & $\%$ \\
\hline Rendah & 42 & 77.8 \\
\hline Tinggi & 12 & 22.2 \\
\hline Jumlah & 54 & 100 \\
\hline
\end{tabular}

Berdasarkan tabel di atas dapat dilihat bahwa Tingkat Pendidikan pada 54 responden hampir seluruh responden memiliki tingkat pendidikan rendah $(77.8 \%)$.

Tabel 5: Distribusi Frekuensi Responden Berdasarkan Status Ekonomi

\begin{tabular}{|c|c|c|}
\hline Status Ekonomi & $f$ & $\%$ \\
\hline Bawah & 48 & 88.9 \\
\hline Atas & 6 & 11.1 \\
\hline Jumlah & 54 & 100 \\
\hline
\end{tabular}

Berdasarkan tabel di atas dapat dilihat bahwa status ekonomi pada 54 responden hampir seluruh responden berstatus ekonomi kelas bawah (88.9\%).

Tabel 6: Distribusi Frekuensi Responden Berdasarkan Tingkat Kecemasan

\begin{tabular}{|c|c|c|}
\hline Tingkat Kecemasan & f & $\%$ \\
\hline Ringan & 7 & 13 \\
\hline Sedang & 13 & 24.1 \\
\hline Berat & 34 & 63 \\
\hline Panik & 0 & 0 \\
\hline Jumlah & 54 & 100 \\
\hline
\end{tabular}

Berdasarkan tabel di atas dapat dilihat bahwa tingkat kecemasan pada 54 responden sebagian besar responden cemas berat $(63 \%)$. 
Analisis Bivariat

Tabel 7: Hubungan Tingkat Pengetahuan dengan Tingkat Kecemasan Pada Pasien TB Paru

\begin{tabular}{lcccccccc}
\hline \multirow{2}{*}{$\begin{array}{l}\text { Tingkat } \\
\text { Pengetahuan }\end{array}$} & \multicolumn{7}{c}{ Kecemasan } & \multirow{2}{*}{ Total } \\
\cline { 2 - 8 } & Ringan & \multicolumn{2}{c}{ Sedang } & \multicolumn{1}{c}{ Berat } & & \\
\cline { 2 - 8 } & f & $\%$ & $\mathrm{f}$ & $\%$ & $\mathrm{f}$ & $\%$ & $\mathrm{f}$ & $\%$ \\
\hline Baik & 1 & 25 & 2 & 50 & 1 & 25 & 4 & 100 \\
\hline Cukup & 3 & 17,6 & 8 & 47,1 & 6 & 35,3 & 17 & 100 \\
\hline Kurang & 3 & 9,1 & 3 & 9,1 & 27 & 81,8 & 33 & 100 \\
\hline Total & 7 & 13 & 13 & 24 & 34 & 63 & 54 & 100 \\
\hline p value & \multicolumn{7}{|c|}{0,008} \\
\hline
\end{tabular}

Berdasarkan tabel di atas menunjukan bahwa berdasarkan analisis uji Chi Square ada hubungan antara tingkat pengetahuan dengan tingkat kecemasan $p$ value 0.008 ( $p$-value $\leq 0.05)$ sehingga Ho ditolak dan Ha diterima.

Tabel 8: Hubungan Usia dengan Tingkat Kecemasan Pada Pasien TB Paru

\begin{tabular}{|c|c|c|c|c|c|c|c|}
\hline \multirow{3}{*}{ Usia } & \multicolumn{6}{|c|}{ Kecemasan } & \multirow{2}{*}{ Total } \\
\hline & \multicolumn{2}{|c|}{ Ringan } & \multicolumn{2}{|c|}{ Sedang } & \multicolumn{2}{|c|}{ Berat } & \\
\hline & $\mathrm{f}$ & $\%$ & $\mathrm{f}$ & $\%$ & $\mathrm{f}$ & $\%$ & $\%$ \\
\hline Tua & 2 & 6,1 & 4 & 12,1 & 27 & 81,8 & $33 \quad 100$ \\
\hline Muda & 5 & 23,8 & 9 & 42,9 & 7 & 33,3 & 21100 \\
\hline Total & 7 & 13 & 13 & 24 & 34 & 63 & 54100 \\
\hline p value & & & & 0,0 & & & \\
\hline
\end{tabular}

Berdasarkan tabel di atas menunjukan bahwa berdasarkan analisis uji Chi Square ada hubungan antara usia dengan tingkat kecemasan p-value 0.002 ( $p$-value $\leq 0.05)$.

Tabel 9: Hubungan Jenis Kelamin dengan Tingkat Kecemasan Pada Pasien TB Paru

\begin{tabular}{lcccccccc}
\hline \multirow{3}{*}{ Usia } & \multicolumn{9}{c}{ Kecemasan } & \multirow{2}{*}{ Total } \\
\cline { 2 - 9 } & \multicolumn{2}{c}{ Ringan } & \multicolumn{2}{c}{ Sedang } & \multicolumn{3}{c}{ Berat } & \\
\cline { 2 - 9 } & $\mathrm{f}$ & $\%$ & $\mathrm{f}$ & $\%$ & $\mathrm{f}$ & $\%$ & $\mathrm{f}$ & $\%$ \\
\hline Perempuan & 2 & 6,5 & 3 & 9,7 & 26 & 83,8 & 31 & 100 \\
\hline Laki-laki & 5 & 21,7 & 10 & 43,5 & 8 & 34,8 & 23 & 100 \\
\hline Total & 7 & 13 & 13 & 24 & 34 & 63 & 54 & 100 \\
\hline p value & \multicolumn{8}{c}{0,008} \\
\hline
\end{tabular}

Berdasarkan tabel di atas menunjukan bahwa berdasarkan analisis uji Chi Square ada hubungan antara jenis kelamin dengan tingkat kecemasan $p$-value 0.008 ( $p$-value $\leq 0.05)$.

Tabel 10: Hubungan Tingkat Pendidikan dengan Tingkat Kecemasan Pada Pasien TB Paru

\begin{tabular}{lcccccccc}
\hline \multirow{2}{*}{ Tingkat } & \multicolumn{8}{c}{ Kecemasan } \\
\cline { 2 - 8 } Pendidikan & Ringan & \multicolumn{3}{c}{ Sedang } & \multicolumn{3}{c}{ Berat } & \multirow{2}{*}{ Total } \\
\cline { 2 - 9 } & $\mathrm{f}$ & $\%$ & $\mathrm{f}$ & $\%$ & $\mathrm{f}$ & $\%$ & $\mathrm{f}$ & $\%$ \\
\hline Rendah & 3 & 7,1 & 7 & 16,7 & 32 & 76,2 & 42 & 100 \\
\hline Tinggi & 4 & 33,3 & 6 & 50 & 2 & 16,7 & 12 & 100 \\
\hline Total & 7 & 13 & 13 & 24 & 34 & 63 & 54 & 100 \\
\hline$p$ value & \multicolumn{7}{c}{0,001} \\
\hline
\end{tabular}

Berdasarkan tabel di atas menunjukan bahwa berdasarkan analisis uji Chi Square ada hubungan antara tingkat pendidikan dengan tingkat kecemasan $p$ value 0.001 ( $p$-value $\leq 0.05)$.

Tabel 11: Hubungan Status Ekonomi dengan Tingkat Kecemasan Pada Pasien TB Paru

\begin{tabular}{lcccccccc}
\hline \multirow{2}{*}{$\begin{array}{c}\text { Status } \\
\text { Ekonomi }\end{array}$} & \multicolumn{9}{c}{ Kecemasan } \\
\cline { 2 - 8 } & Ringan & \multicolumn{3}{c}{ Sedang } & \multicolumn{3}{c}{ Berat } & \multirow{2}{*}{ Total } \\
\cline { 2 - 8 } & $\mathrm{f}$ & $\%$ & $\mathrm{f}$ & $\%$ & $\mathrm{f}$ & $\%$ & $\mathrm{f}$ & $\%$ \\
\hline Bawah & 5 & 10,4 & 9 & 18,8 & 34 & 70,8 & 48 & 100 \\
\hline Atas & 2 & 33,3 & 4 & 66,7 & 0 & 0 & 6 & 100 \\
\hline Total & 7 & 13 & 13 & 24 & 34 & 63 & 54 & 100 \\
\hline p value & \multicolumn{8}{c}{0,003} \\
\hline
\end{tabular}

Berdasarkan tabel di atas menunjukan bahwa berdasarkan analisis uji Chi Square ada hubungan antara status ekonomi dengan tingkat kecemasan $p$ value 0.003 ( $p$-value $\leq 0.05)$.

\section{PEMBAHASAN}

\section{Hubungan tingkat pengetahuan dengan tingkat kecemasan pada pasien $\mathrm{TB}$ paru}

Berdasarkan hasil penelitian dapat dilihat bahwa dari 54 responden dari karakteristik tingkat pengetahuan yang memiliki tingkat pengetahuan kurang sebanyak 33 responden $(61.5 \%)$, dari karakteristik kecemasan yang memiliki kecemasan berat sebanyak 34 responden (63\%), responden yang memiliki tingkat pengetahuan kurang dengan kecemasan 
berat sebanyak 27 responden. Dari hasil analisis uji Chi Square ada hubungan antara Tingkat Pengetahuan dengan tingkat kecemasan p-value 0.008 ( $p$-value $\leq$ $0.05)$.Hal ini terjadi karena kurang nya informasi dan pengetahuan yang dimiliki oleh responden tentang tuberkulosis paru.Perlunya pendidikan kesehatan tentang tuberkulosis paru kepada responden untuk menambah informasi dan pengetahuan tentang tuberkulosis paru agar dapat mengurangi rasa kecemasannya (Notoadmodjo, 2007). Semakin banyak pengetahuan yang dimiliki seseorang maka seseorang tersebut akan lebih siap menghadapi sesuatu dan dapat mengurangi kecemasan. Ketidaktahuan terhadap suatu hal dianggap sebagai tekanan yang dapat mengakibatkan krisis dan dapat menimbulkan kecemasan.Kecemasan dapat terjadi pada individu dengan tingkat pengetahuan yang rendah, disebabkan karena kurangnya informasi yang diperoleh.

Tingkat pengetahuan seseorang memiliki hubungan positif terhadap tingkat kecemasan yang dirasakan seseorang (Hawari, 2001). Semakin tinggi tingkat pengetahuan responden maka tingkat kecemasannya semakin rendah karena semakin tinggi pengetahuan semakin besar kemampuan menyerap dan menerima informasi sehingga pengetahuan dan wawasan lebih luas (Suparyanto, 2011). Tingkat pengetahuan seseorang yang rendah akan cenderung lebih mudah mengalami kecemasan dibanding seseorang yang mempunyai tingkat pengetahuan yang tinggi (Hidayat, 2004).

Penelitian ini sesuai dengan penelitian umar (2003) yang menyatakan terdapat pengaruh yang signifikan antara pengetahuan dengan kecemasan pasien tuberkulosis paru, dimana jika Pengetahuan rendah maka Kecemasan tinggi, jika Pengetahuan sedang maka Kecemasan sedang dan jika pengetahuan tinggi maka kecemasan rendah.

\section{Hubungan usia dengan tingkat kecemasan pada pasien TB paru}

Berdasarkan hasil penelitian dapat dilihat bahwa dari 54 responden dari karakteristik usia yang masuk kategori usia tua sebanyak 33 responden $(61.1 \%)$, dari karakteristik kecemasan yang memiliki kecemasan berat sebanyak 34 responden (63\%), responden yang masuk kategori usia tua dengan kecemasan berat sebanyak 27 responden. Berdasarkan analisis uji Chi Square ada hubungan antara usia dengan tingkat kecemasan p-value 0.002 ( $p$-value $\leq 0.05)$. Hal ini terjadi karena kurang perhatian dari orang-orang terdekat.Perlunya dukungan dan motivasi dari orang-orang terdekat untuk meningkatkan rasa semangat pada diri responden yang dapat mengurangi kecemasannya (Jong, 2005).Usia merupakan salah satu faktor internal yang berkontribusi terhadap timbulnya kecemasan pada orang tua. Penelitian ini sejalan dengan hasil penelitian Priyatin (2007) yang menyatakan ada hubungan yang signifikan antara faktor usia dengan tingkat kecemasan. Ditambahkan dalam penelitian Arifin (2005), bahwa faktor usia memberikan kontribusi terhadap teriadinya kecemasan.

\section{Hubungan jenis kelamin dengan tingkat kecemasan pada pasien TB paru}

Berdasarkan hasil penelitian dapat dilihat bahwa dari 54 responden dari karakteristik jenis kelamin yang berjenis kelamin perempuan sebanyak 31 responden (57.4\%), dari karakteristik tingkat kecemasan yang memiliki kecemasan berat sebanyak 34 responden $(63 \%)$, responden yang berjenis Kelamin perempuan dengan kecemasan berat sebanyak 26 responden. Berdasarkan hasil analisis uji Chi Square ada hubungan antara jenis kelamin dengan tingkat kecemasan $p$-value 0.008 ( $p$-value $\leq$ 0.05).Hal ini terjadi karena responden peremplebih sensitif dalam memikirkan penyakitnya dan merasa kurang percaya diri.Perlu adanya dukungan dan motivasi untuk meningkatkan rasa percaya diri yang 
dapat mengurangi kecemasannya (Stolte, 2004).

Penelitian ini sesuai dengan beberapa teori diantaranya ; stuart dan sundenn (1998) yang menyatakan bahwa perempuan lebih mudah mengalami cemas daripada laki-laki. Perempuan cenderung lebih mudah mengalami kecemasan dibandingkan laki-laki. Hal ini dikarenakan perempuan lebih sensitif terhadap permasalahan, sehingga mekanisme koping perempuan lebih kurang baik di banding kan laki-laki (Gunarso, 2005).

Penelitian ini sejalan dengan hasil penelitian Priyatin (2007) yang menyatakan bahwa ada hubungan yang kuat dan signifikan antara jenis kelamin dengan kecemasan pada pasien dan keluarga terhadap TB Paru, seperti halnya penelitian yang dilakukan oleh Junait (2003) yang mengatakan bahwa ada hubungan antara jenis kelamin dengan tingkat kecemasan.

\section{Hubungan tingkat pendidikan dengan tingkat kecemasan pada pasien TB paru}

Berdasarkan hasil penelitian dapat dilihat bahwa dari 54 responden dari karakteristik tingkat pendidikan yang masuk kategori tingkat Pendidikan rendah sebanyak 42 responden $(77.8 \%)$, dari karakteristik kecemasan yang memiliki kecemasan berat sebanyak 34 responden (63\%), responden yang memiliki tingkat pendidikan rendah dengan kecemasan berat sebanyak 32 responden. Berdasarkan hasil analisis uji Chi Square ada hubungan antara tingkat pendidikan dengan tingkat kecemasan $p$-value 0.001 ( $p$-value $\leq$ 0.05).Hal ini berhubungan dengan tingkat pengetahuan rendah yaitu terjadi karena kurangnya informasi dan pengetahuan yang dimiliki oleh responden.Perlu adanya pendidikan kesehatan untuk menambah informasi dan pengetahuan agar dapat mengurangi kecemasannya (Machfoed, 2005).

Makin tinggi tingkat pendidikan seseorang, semakin jarang mengalami kecemasan yang berat karena mudah dalam menerima informasi sehingga semakin banyak pula pengetahuan yang dimiliki. Sebaliknya pendidikan yang kurang akan menghambat perkembangan sikap seseorang terhadap nilai yang baru di perkenalkan untuk menghadapi suatu masalah (Kuncoroningrat, 1997, dikutip oleh Nursalam dan Pariani, 2001). Tingkat pendidikan rendah pada seseorang akan lebih mudah mengalami kecemasan karena semakin tinggi tingkat pendidikan nya akan berpengaruh terhadap kemampuan berfikir nya (stuart \& sundeen, 2000). Tingkat pendidikan yang cukup akan lebih mudah dalam mengiden tifikasi stresor dalam diri sendiri maupun dari luar dirinya. Tingkat pendidikan juga mempengaruhi kesadaran dan pemahaman terhadap stimulus (Jatman, 2000).

Hasil penelitian ini sejalan dengan hasil penelitian Priyatin (2007) bahwa ada hubungan yang kuat dan signifikan antara pendidikan dengan kecemasan, seperti halnya penelitian yang dilakukan oleh Junait (2003) dengan hasil ada hubungan antara tingkat pendidikan dengan tingkat kecemasan. Penelitian Astria (2004) yang menyatakan ada hubungan yang signifikan antara tingkat pendidikan dengan kecemasan pasien TB. Penelitian yang serupa tentang faktor-faktor yang mempengaruhi tingkat kecemasan orang tua oleh Maryaningtyas (2005), menunjukkan bahwa faktor pendidikan adalah salah satu faktor eksternal yang dapat berkontribusi terhadap kecemasan seseorang

\section{Hubungan status ekonomi dengan tingkat kecemasan pada pasien TB paru}

Berdasarkan hasil penelitian dapat dilihat bahwa dari 54 responden dari karakteristik status ekonomi yang masuk kategori status ekonomi kelas bawah sebanyak 48 responden $(88.9 \%)$, dari karakteristik kecemasan yang memiliki kecemasan berat sebanyak 34 responden $(63 \%)$, responden yang masuk status ekonomi rendah dengan kecemasan berat sebanyak 34 responden. Berdasarkan analisis uji Chi Square ada hubungan 
antara status ekonomi dengan tingkat kecemasan $p$-value 0.003 ( $p$-value $\leq$ $0.05)$.Hal ini terjadi karena adanya beban pikiran untuk biaya sehari-hari yang harus dikeluarkan selama sakit. Untuk hal ini perlu adanya kerja sama lintas sektoral untuk pemberdayaan masyarat untuk meningkatkan kesejahteraan ekonomi masyarakat, ini sesuai dengan undangundang Nomor 17 tahun 2007 tentang Rencana Pembangunan Jangka Panjang Nasional (RPJP-N) tahun 2005-2025 mencantumkan bahwa: Pembangunan bidang kesehatan diarahkan salah satunya pada kemampuan hidup sehat bagi setiap orang agar peningkatan derajat kesehatan masyarakat yang setinggi-tingginya dapat terwujud. Pembangunan kesehatan dilaksanakan melalui peningkatan upaya kesehatan, sumber daya manusia kesehatan, obat dan perbekalan kesehatan yang ditandai oleh peningkatan pengawasan dan pemberdayaan masyarakat serta manajemen kesehatan.

Penelitian ini sesuai dengan beberapa teori diantaranya ; stuart dan sundenn (1998) yang menyatakan bahwa Status ekonomi yang rendah pada seseorang menyebabkan orang tersebut mengalami stres cemas dan dibanding dengan mereka yang status pendidikan dan status ekonomi yang tinggi. Status ekonomi yang rendah umumnya memiliki tekanan dan tuntutan yang lebih tinggi untuk menghadapi kehidupan sehingga mudah mengalami cemas dalam menghadapi masalah.

Faktor lain yang mempengaruhi kecemasan antara lain ancaman terhadap integritas biologi yaitu meliputi ketidakmampuan fisiologis yang akan datang atau menurunnya kapasitas untuk melakukan aktifisehari-hari dapat berupa penyakit trauma fisik dan ancaman terhadap konsep diri dan harga diri yaitu meliputi proses kehilangan, perubahan peran, perubahan hubungan, dan status ekonomi (Kaplan \& Sadock, 2000).

Penelitan ini sejalan dengan penelitian Priyatin (2007) bahwa ada hubungan yang kuat dan signifikan antara ekonomi dengan kecemasan, seperti halnya penelitian yang dilakukan oleh Junait
(2003) dengan hasil ada hubungan antara tingkat sosial ekonomi dengan tingkat kecemasan. Hal ini dikuatkan dalam penelitian Maryaningtyas (2005), bahwa faktor ekonomi adalah salah satu faktor yang dapat berkontribusi terhadap timbulnya kecemasan.

\section{KESIMPULAN}

Faktor-faktor yang berhubungan dengan tingkat kecemasan pasien TB paru yaitu: tingkat pengetahuan, usia, jenis kelamin, tingkat pendidikan, dan status ekonomi. Sebagian besar responden memiliki tingkat pengetahuan kurang, sebagian besar responden kategori usia tua, sebagian besar responden berjenis kelamin perempuan, hampir seluruh responden memiliki tingkat pendidikan rendah, dan hampir seluruh responden berstatus ekonomi kelas bawah.Ada hubungan antara tingkat pengetahuan, usia,jenis kelamin, pendidikan, status ekonomi dengan tingkat kecemasan.

Hasil penelitian ini dijadikan bahan masukan untuk membuat kebijakan kepada perawat untuk lebih meningkatkan pelayanan keperawatan berupa penyuluhan tentang tuberkulosis, memberikan dukungan sosial kepada pasien usia tua, memberikan motivasi kepada pasien perempuan. Memberikan masukan kepada pemerintah daerah tentang kondisi status ekonomi pasien agar dicarikan solusi untuk meningkatkan kesejahteraan ekonomi yang dapat meningkatkan derajat kesehatan.

Sebaiknya meningkatkan kualitas dan kuantitas pendidikan kesehatan tentang tuberkulosis paru untuk memberikan informasi dan meningkatkan pengetahuan pasien agar dapat mengurangi rasa kecemasan pasien.Memberikan motivasi dan memberikan masukan kepada anggota keluarga untuk memberikan perhatian lebih kepada pasien usia tua agar meningkatkan rasa semangat yang dapat mengurangi kecemasan. Memberikan motivasi kepada pasien perempuan dan memberikan masukan kepada anggota keluarga untuk memberikan motivasi 
kepada pasien perempuan agar meningkatkan rasa percaya diri yang dapat mengurangi kecemasan.

\section{DAFTAR PUSTAKA}

Depkes RI. (2012). Profil Kesehatan Indonesia 2011.http://www.depkes.go.id.

Dinkes Garut. (2012). Profil Kesehatan Kabupaten Garut 2011 .Dinkes Kab Garut :Garut.

Dinkes Jabar. (2012). Profil Kesehatan Jawa Barat 2011.http://www.depkes.go.id

Hawari.(2006). Manajemen Stress, Cemas, Depresi. Jakarta, FKUI.

Hidayat.(2004). Pengantar Konsep Dasar Keperawatan.Jakarta : Salemba Medika.

Jatman D. (2001).Psikologi Perkembangan Edisi 1. Semarang : Badan Penerbit Diponegoro.

Jaorana, dkk. (2009). Pelatihan Penanggulangan Tuberkulosis Bagi
Kader Komunitas. Jakarta: GF ATM-TB ROUND 8.

Manaf, dkk.(2006). Pedoman Nasional Penanggulangan Tuberkulosis, Edisi 2. Jakarta: DEPKES RI.

Nursalam. (2003). Konsep dan Penerapan Metodologi Penelitian Ilmu Keperawatan : Pedoman Skripsi, Tesis dan Instrumen Penelitian. Jakarta : Salemba Medika.

Notoatmodjo. (2007). Pendidikan dan Perilaku Kesehatan.Jakarta : Rineka Cipta

Potter, P.A, Perry, A.G. (2005). Buku Ajar Fundamental Keperawatan : Konsep, Proses, dan Praktik.Edisi 4.Volume 2. Jakarta:EGC.

PPTI.(2010). Buku Saku PPTI.www.ppti.info.

Smeltzer, S.C. and Bare, B.G. (2008).Buku Ajar Keperawatan Medikal Bedah. Edisi 8 Vol.2.Jakarta : EGC.

Stuart, G. W. (2007). Buku Saku Keperawatan Jiwa .Edisi 5. Jakarta. 